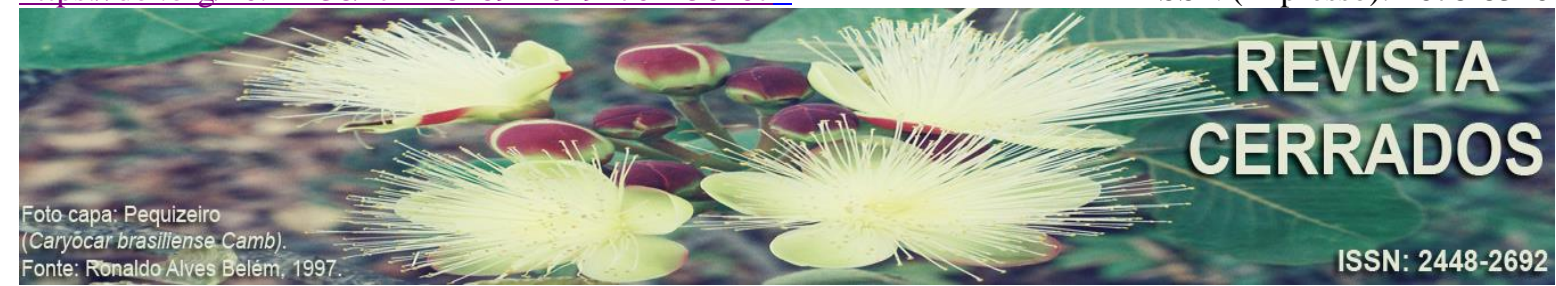

\title{
ÁREAS VERDES DE ARAXÁ (MG): questões socioambientais da "Matinha" do bairro Boa Vista
}

\section{GREEN AREAS OF ARAXÁ (MG): socio-environmental issues of the "Matinha" of the Boa Vista neighborhood}

\section{ÁREAS VERDES DE ARAXÁ (MG): cuestiones socioambientales de la "Matinha" del bairro Boa Vista}

\author{
Luis Guilherme Ferreira Leite \\ Universidade Federal de Uberlândia - UFU \\ E-mail: < lgfleite@gmail.com>.
}

\begin{abstract}
RESUMO
As áreas verdes são essenciais para manutenção da qualidade de vida em espaços urbanos. Contudo, esses locais que auxiliam no equilíbrio ecológico das cidades estão cada vez mais ausentes. Diante do quadro, o presente artigo tem como objetivo analisar os problemas de degradação ambiental da área verde do bairro Boa Vista conhecida como "Matinha" em Araxá - Minas Gerais. O trabalho inclui a percepção da população local em relação à área no contexto geográfico do bairro. Para alcançar o objetivo proposto, os procedimentos metodológicos incluem, revisão bibliográfica sobre a temática, trabalhos de campo no local e uma pesquisa empírica com aplicação de questionários. Os resultados obtidos serão apresentados por meio de análises descritivas, fotografias, mapas, gráficos e tabelas. Após análise, conclui-se que a área verde do bairro Boa Vista não recebe atenção do poder público e soma-se a isso, a degradação da "Matinha" por parte de moradores próximos. Cabe salientar que a transformação da realidade atual só será possível através de uma parceria entre comunidade e governo. A realização de um minucioso trabalho de conscientização ambiental com a população local é essencial para equilibrar o convívio entre sociedade e natureza.
\end{abstract}

Palavras-chave: Áreas de Preservação Permanente. Conflitos Socioambientais. Degradação Ambiental. Meio Ambiente.

\begin{abstract}
Green areas are essential for maintaining the quality of life in urban spaces. However, these sites that help in the ecological balance of cities are increasingly absent. In view of the table, this article aims to analyze the environmental degradation problems of the green area of the Boa Vista neighborhood known as "Matinha" in Araxá - Minas Gerais. The work includes the
\end{abstract}


perception of the local population regarding the area in the geographical context of the neighborhood. In order to reach the proposed objective, the methodological procedures include, bibliographic review on the subject, on-site fieldwork and an empirical research with application of questionnaires. The results obtained will be presented through descriptive analyzes, photographs, maps, graphs and tables. After analysis, it is concluded that the green area of the Boa Vista neighborhood receives no attention from the public power and adds to that, the degradation of the Matinha by nearby residents. It should be noted that the transformation of the current reality will only be possible through a partnership between community and government. Performing a thorough environmental awareness work with the local population is essential to balance the relationship between society and nature.

Keywords: Permanent Preservation Areas. Socioenvironmental Conflicts. Environmental Degradation. Environment.

\section{RESUMEN}

Las áreas verdes son esenciales para el mantenimiento de la calidad de vida en espacios urbanos. Sin embargo, esos lugares que auxilian en el equilibrio ecológico de las ciudades están cada vez más ausentes. Ante el cuadro, el presente artículo tiene como objetivo analizar los problemas de degradación ambiental del área verde del barrio Boa Vista conocida como "Matinha" en Araxá - Minas Gerais. El trabajo incluye la percepción de la población local en relación al área en el contexto geográfico del barrio. Para alcanzar el objetivo propuesto, los procedimientos metodológicos incluyen, revisión bibliográfica sobre la temática, trabajos de campo en el local y una investigación empírica con aplicación de cuestionarios. Los resultados obtenidos serán presentados por medio de análisis descriptivos, fotografías, mapas, gráficos y tablas. Después del análisis, se concluye que el área verde del barrio Boa Vista no recibe atención del poder público y se suma a ello, la degradación de la "Matinha" por parte de vecinos cercanos. Cabe señalar que la transformación de la realidad actual sólo será posible a través de una asociación entre comunidad y gobierno. La realización de un minucioso trabajo de concientización ambiental con la población local es esencial para equilibrar la convivencia entre sociedad y naturaleza.

Palabras clave: Áreas de Preservación Permanente. Conflictos Socioambientales. Degradación Ambiental. Medio Ambiente.

\section{INTRODUÇÃO}

As cidades brasileiras, atualmente, convivem com inúmeros problemas de diversos aspectos, entre eles, estão os conflitos com as áreas ambientais no meio urbano. Um grande desafio que por hora se apresenta às cidades de todos os portes, e com interesse especial àquelas em transição de pequena para média ${ }^{1}$, é a valorização do meio ambiente.

\footnotetext{
${ }^{1}$ O IBGE (2014, p. 5) classifica em municípios de médio porte aqueles que apresentam entre 100 e 500 mil habitantes de população. 
LEITE, L. G. F.

Áreas verdes de Araxá (MG): questões socioambientais da "Matinha" do bairro Boa Vista

Ressalta-se a importância do crescimento ordenado, valorizando as questões ambientais, ofertando qualidade de vida aos moradores.

As áreas verdes nas cidades são benéficas a sociedade. Essas são remanescentes florestais em meio às manchas urbanas que preservam nascentes e exemplares da fauna e da flora. Dentre os locais, que se caracterizam como áreas verdes urbanas, estão as Áreas de Preservação Permanentes (APP's). Segundo o Código Florestal Brasileiro (2012), as APP's são locais destinados à proteção dos recursos hídricos, paisagem, estabilidade geológica, biodiversidade e fluxo de fauna e flora.

As APP's, de acordo com o Ministério do Meio Ambiente (MMA), podem exercer um papel fundamental na dinâmica dos centros urbanos:

\begin{abstract}
A manutenção das APP's, em meio urbano, possibilita a valorização da paisagem e do patrimônio natural e construído (de valor ecológico, histórico, cultural, paisagístico e turístico). Esses espaços exercem, do mesmo modo, funções sociais e educativas relacionadas com a oferta de campos esportivos, áreas de lazer e recreação, oportunidades de encontro, contato com os elementos da natureza e educação ambiental (voltada para a sua conservação), proporcionando uma maior qualidade de vida às populações urbanas[...] (MMA, 2013).
\end{abstract}

Dessa forma, uma APP pode ser um instrumento com capacidade de fornecer qualidade de vida enquanto exerce o valor da conservação ambiental, muitas vezes esquecida pelos poderes públicos dos municípios brasileiros. Além das APP's, a criação de praças, parques e outros equipamentos públicos que promovam a saúde e a qualidade de vida, são fundamentais na dinâmica urbana.

Em Minas Gerais, a cidade de Araxá possui cerca de 105 mil habitantes de acordo com o Instituto Brasileiro de Geografia e Estatística (IBGE, 2018). A cidade é um importante polo minerador, destaque na economia estadual. Araxá também é conhecida nacionalmente pelo Complexo Hidromineral do Barreiro, local famoso pelos banhos de lama e suas águas termais. A cidade apresenta inúmeras áreas verdes, a maior delas, localizada na Zona Oeste de Araxá no bairro Boa Vista.

A área verde natural do bairro Boa Vista, objeto de estudo deste artigo, é conhecida pelos moradores como "Matinha" e, atualmente, encontra-se em estado de conservação precário, principalmente em seu entorno. Durante visitas ao local, observa-se a necessidade de aplicação de medidas conservacionistas, pois a área pode cumprir um papel essencial na dinâmica urbana da região voltada para o meio ambiente e, ainda, oferecer 
LEITE, L. G. F.

Áreas verdes de Araxá (MG): questões socioambientais da "Matinha" do bairro Boa Vista

suporte às atividades de recreação e de lazer dos moradores, desde que preparada adequadamente. Outro ponto importante é que o local abriga nascentes que compõe a Bacia Hidrográfica do Rio Araguari (MG), além de ser uma extensão de matas ripárias do Cerrado na área urbana de Araxá.

Diante do quadro, o objetivo deste artigo é analisar os problemas de degradação ambiental da área verde do bairro Boa Vista, inclusive a percepção da população local em relação ao remanescente ambiental como componente do espaço geográfico do bairro. Para se alcançar o objetivo, a metodologia consiste em um levantamento bibliográfico sobre o tema, realização de trabalhos de campo em toda a área verde e ruas do bairro Boa Vista, coleta fotográfica e análise das condições ambientais da área, permitindo compreender a realidade vivenciada pelos moradores. Realizou-se também uma pesquisa empírica com a aplicação de um questionário aos moradores da região, salientando os problemas encontrados e observados nos trabalhos de campo.

Este artigo se organiza da seguinte forma, no primeiro momento, este tópico inicial apresenta o tema, aponta o objetivo e a metodologia da pesquisa. Em seguida, realizase a discussão teórica acerca do tema em que são abordados os temas: Cerrado, Áreas de Preservação Permanente (APP's), áreas verdes em espaços urbanos. Aproveitamos a discussão teórica para observar apontamentos sobre as áreas verdes em espaços urbanos que estão elencados no Plano Diretor Estratégico de Araxá. Adiante, apresentam-se os resultados, subdivididos em dois tópicos, os trabalhos de campo ilustrados por fotografias e materiais cartográficos; e a discussão da pesquisa com os habitantes locais estruturada em gráficos e tabelas. Por fim, apresenta-se as considerações finais com apontamentos e conclusões.

\section{NATUREZA E DIVERSIDADE: PONDERAÇÕES TEÓRICO-CONCEITUAIS}

\section{Cerrado}

O Cerrado brasileiro ocupa uma área de dois milhões de quilômetros quadrados, o que corresponde a cerca de $22 \%$ do território nacional, de acordo com o Ministério do Meio Ambiente (2014). Considerado um ícone mundial de biodiversidade, é necessário ressaltar a grande importância do Cerrado brasileiro para a escala social. Apelidado como berço das 
LEITE, L. G. F.

Áreas verdes de Araxá (MG): questões socioambientais da "Matinha" do bairro Boa Vista

águas, dados do WWF-Brasil (2014) apontam que mais de 25 milhões de pessoas vivem em áreas de Cerrado no Brasil que possui entre seus habitantes índios, quilombolas e ribeirinhos.

Inúmeras espécies vegetais e animais da região correm o risco de extinção. Entre as plantas, existem aquelas com propriedades medicinais que ajudam a curar doenças; outras são proteções naturais contra fenômenos geográficos como a degradação do solo e a erosão; atuam ainda, como barreira natural contra o vento; e muitas espécies cumprem, nas savanas brasileiras, a função de criação de habitat para predadores naturais de pragas.

Um quadro contraproducente que ameaça o Cerrado é a expansão da fronteira agrícola, que pode ser explicada pela monotonia, já que as paisagens do Cerrado sempre parecem ser as mesmas. Contudo, Ab'Saber chama a atenção para essa situação, explicando melhor a formação desse vasto bioma:

A combinação de fatos físicos, ecológicos e biótico que caracteriza o domínio dos cerrados é, na aparência, de relativa homogeneidade, extensível a grandes espaços. A repetitividade das paisagens vegetais ligadas ao tema dos cerrados - cerrados, cerradões, campestres de diversos tipos - contribui muito para o caráter monótono desse grande conjunto paisagístico. Mesmo, entretanto, do ponto de vista exclusivamente morfológico, o domínio dos cerrados apresenta sutis diferenciações de padrões de paisagens em funções de fatores litológicos e estruturais (AB'SABER, 2012, p. 118).

Dessa maneira, as análises sobre a formação do cerrado vão além da monotonia alcançada pelos olhos humanos. Existem variados fatores que dão suporte para as incalculáveis riquezas encontradas no bioma, entre elas podemos citar a formação pedológica - com a presença de latossolos; vertentes de drenagem- que podem ocorrer em estruturas dobradas aplainadas- trazendo características únicas ao sistema de águas.

A falta de conhecimento das riquezas naturais do bioma contribui para os inúmeros impactos causados em seus recursos. A caça predatória continua a existir e coloca, diariamente, inúmeras espécies em possibilidade de extinção. Ligada à agropecuária, as queimadas desenfreadas para expansão de áreas de cultivo e pastagem e o uso exagerado de agrotóxicos nas plantações consistem em riscos na conservação do Cerrado.

Embora haja ampla defesa contra o avanço da fronteira agrícola no cerrado, é preciso entender que grande parte do bioma é tomada pela agricultura e, dessa forma, faz-se necessário a criação de políticas de planejamento, principalmente no que diz respeito à gestão dos recursos hídricos. Lima e Silva (2008, p. 6) apontam que: 
LEITE, L. G. F.

Áreas verdes de Araxá (MG): questões socioambientais da "Matinha" do bairro Boa Vista

O uso adequado dos recursos hídricos do Cerrado, (...) é fundamental, não apenas para a população e o meio ambiente da região, mas para grande parte do país, em termos econômicos e socioambientais, uma vez que ocupa a parte mais alta de suas grandes regiões hidrográficas.

Os inúmeros recursos hídricos existentes no Cerrado são fundamentais na dinâmica hidrográfica de todo o território brasileiro, pois, nesse bioma, são encontradas nascentes de três grandes bacias hidrográficas: Amazonas, Paraná e São Francisco. É preciso ficar atento a todos os tipos de nascentes existentes, dos pequenos córregos até aqueles que formam grandes rios. Outro ponto importante é a conservação de mananciais existentes em áreas urbanas, que deixam o ambiente das cidades e segue caminho até os grandes rios.

Em conjunto com nascentes existente em cidades, as matas nativas do Cerrado se fazem presentes e contribuem significativamente no equilíbrio ecológico dos ambientes em que se encontram. As áreas nativas, em extensões urbanas, protegem mananciais e servem como aparato para a qualidade de vida e bem-estar social, sendo comumente encontradas em cidades presentes no bioma Cerrado.

\section{A importância das Áreas de Preservação Permanente}

As Áreas de Preservação Permanente (APP's) são de fundamental importância para a conservação e preservação de espécies da fauna e flora, presentes nos mais variados biomas do Brasil. As APP's, em grande parte, desempenham papel essencial, pois ajudam a garantir os fluxos gênicos de espécies e contribuem para a manutenção do Meio Ambiente, de tal maneira mitigam impactos ambientais causados por caráter natural e antrópicos. Por isso constituem, por lei, áreas de conservação naturais.

A existência de APP's em áreas urbanas gera intensos debates e discussões, pois seu manejo deve ser realizado com cuidado e faz-se necessário uma política bem precisa no que tange a sua proteção. O Ministério do Meio Ambiente defende que:

Os efeitos indesejáveis do processo de urbanização sem planejamento, como a ocupação irregular e o uso indevido dessas áreas, tende a reduzi-las e degradá-las cada vez mais. Isso causa graves problemas nas cidades e exige um forte empenho no incremento e aperfeiçoamento de políticas ambientais urbanas voltadas à recuperação, manutenção, monitoramento e fiscalização das APP's nas cidades (MMA, 2013, p. 1). 
LEITE, L. G. F.

Áreas verdes de Araxá (MG): questões socioambientais da "Matinha" do bairro Boa Vista

As Áreas de Preservação Permanente (APP's), quando consolidadas com políticas ambientais favoráveis, tornam-se além de espaços de conservação da biodiversidade, locais de encontro para a população local que busca qualidade de vida e bem-estar, sendo assim, oferta de contato com a natureza.

O movimento de proteção nas cidades de suas áreas verdes naturais com a criação de APP's é essencial. Devem-se incrementar os instrumentos de conservação do entorno, como por exemplo, garantir que além da metragem definida por lei de área natural, outro extrato seja agregado ao local. A criação de infraestruturas de lazer no entorno dos espaços protegidos para o acesso da população, aliada a realização de trabalhos de conscientização ambiental, quando bem executados, garantem a valorização do entorno, a qualidade ambiental e a oferta de qualidade de vida aos moradores da região e, acima de tudo, proteção dessas áreas nos ambientes urbanos.

\title{
Áreas Verdes e Parques Urbanos
}

Se existem espaços nas cidades que podem cumprir, de forma essencial, a função de facilitadores da qualidade de vida, esses locais são as áreas verdes. De acordo com Loboda e Angelis (2005, p.134):

\begin{abstract}
As áreas verdes urbanas são de extrema importância para a qualidade da vida urbana. Elas agem, simultaneamente, sobre o lado físico e mental do Homem, absorvendo ruídos, atenuando o calor do sol; no plano psicológico, atenua o sentimento de opressão do Homem com relação às grandes edificações; constitui-se em eficaz filtro das partículas sólidas em suspensão no ar, contribui para a formação e o aprimoramento do senso estético, entre tantos outros benefícios.
\end{abstract}

Essas áreas possuem um papel fundamental na relação do homem com o meio urbano e, portanto, requerem grande atenção quanto à sua gestão e conservação. Lapoix (1977), estudioso francês, argumentava sobre a necessidade de uma adesão durável entre vegetação e concreto. Dessa forma, é possível construir uma cidade digna - proporcionando, aos seus moradores, fatores ecológicos essenciais à vida humana.

A cobertura vegetal em ambientes urbanos ainda se apresenta como:

[...] estabilização de determinadas superfícies, obstáculos contra o vento, proteção da qualidade da água, filtração do ar, equilíbrio do índice de umidade, diminuição da poeira em suspensão, redução dos ruídos, interação entre as atividades humanas e o meio ambiente, fornecimento de alimentos, proteção das nascentes e mananciais, 
LEITE, L. G. F.

Áreas verdes de Araxá (MG): questões socioambientais da "Matinha" do bairro Boa Vista

organização e composição de espaços no desenvolvimento das atividades humanas, valorização visual e ornamental, segurança nas calçadas (verde de acompanhamento viário), recreação, quebra das monotonias das cidades, cores relaxantes, estabelecimento de uma escala intermediária entre a humana e a construída, caracterização e sinalização de espaços, etc. (CAVALHEIRO et al, 1999, p.7).

São inúmeros os benefícios em conservar e manter áreas verdes naturais existentes nas cidades. Principalmente no momento atual, em que o ambiente urbano foi tomado por edifícios, dezenas de ruas e avenidas que contribuem com o aumento da temperatura do microclima urbano de forma desagradável e, ainda, interferem na permeabilidade dos solos.

Os ambientes verdes nas cidades, quando são presentes e abundantes, contribuem e atuam de forma positiva no amortecimento de impactos gerados nos núcleos urbanos. Além disso, aproximam homem e natureza, possibilitando o convívio com o meio ambiente.

É preciso muito cuidado para identificar espaços verdes e, também, máxima atenção quanto à sua conservação e manejo. Essas áreas apresentam inúmeras relações conforme coloca Lapoix (1977, p. 332):

Como ecossistemas que são, os espaços verdes constituem a expressão viva das múltiplas interações existentes entre uma biocenose feita de uma fauna e de uma flora e um biótopo-suporte com seu solo, seu subsolo, seu clima. (...) Manejar espaços abertos, portanto, é responder a um certo número de perguntas, é realizar um justo equilíbrio entre as diversas imposições do meio. Uma árvore, um grupo de árvores, formam com o ar ambiente, o solo onde deitam suas raízes e a cobertura deste solo uma entidade viva, cujos componentes, todos, têm sua influência uns sobre os outros.

A promoção de atividades ecológicas, relacionadas ao cotidiano da cidade, traz vida à fauna e à flora em um ambiente que sofreu antropização. Zelar pela preservação de áreas verdes é essencial para manutenção da vida urbana, principalmente na atual conjectura de estruturação do crescimento das cidades.

Os parques, estabelecidos em áreas urbanas, cumprem funções essenciais a manutenção social. São necessários para que haja inclusão, pois facilitam o acesso da população menos favorecida a ferramentas de lazer, sem excluir outras classes sociais; a qualidade ambiental, pois atenua impactos causados pelo cotidiano das cidades como a poluição do ar; além da promoção da conservação, pois se bem geridos, protegem recursos hídricos e inúmeras espécies da fauna e flora. 
LEITE, L. G. F.

Áreas verdes de Araxá (MG): questões socioambientais da "Matinha" do bairro Boa Vista

Kliass (1993) define bem o significado de Parques Urbanos, para ela, eles se apresentam como espaços públicos, com extensões expressivas, onde existe a predominância de ambientes naturais, de cobertura vegetal. Como o objetivo do espaço está na recreação e também leva a proteção das áreas verdes naturais.

Os parques urbanos sustentam o consenso de que são fundamentais nas grandes cidades para o convívio social e o equilíbrio ambiental, no entanto, são necessárias ações de planejamento que direcionem a criação desses espaços para as cidades de menor porte. A existência de parques consolidados nas cidades contribui para o aumento da qualidade de vida e que se refletem nos índices de saúde e bem-estar social. Esses locais tornam-se espelhos de seus frequentadores com ações como atividades físicas coletivas, presença de profissionais de saúde em determinados horários e o convívio entre os moradores, elevam de forma muito positiva a função do parque.

É preciso defender e entender casos de sucesso de cidades no Brasil, que valorizaram políticas públicas para o bem-estar e a qualidade de vida da população, com a criação de um sistema de parques e áreas verdes. Estudos de caso como o realizado na cidade de Curitiba, ${ }^{2}$ mostram que a criação de um sistema de parques e bosques:

[...] preservam a natureza e criam áreas de lazer, melhorando a qualidade de vida dos habitantes da cidade, é claro. Mas os de Curitiba, in fine, contribuíram para preservar fontes de água, para disciplinar o uso do solo (impedindo a favelização e seus problemas sanitários e sociais), para preservar fundos de vale/afluentes do rio Iguaçú, para sanear áreas urbanas, para valorizar os novos bairros que se formaram em seu entorno (cooptando empreendedores imobiliários) e (...), até mesmo, para homenagear homens públicos e etnias, numa perspectiva temática (OLIVEIRA, 1996, p.20).

No caso da capital paranaense, os interesses públicos foram além da perspectiva de criação dos parques para o lazer e qualidade de vida, pois foram pautados em interesses fundamentais, como a proteção dos recursos naturais e o melhor ordenamento e uso do território. Em Araxá, o Plano Diretor Estratégico (PDE) foi revisado e aprovado em 2011 (Lei Municipal 5.998) $)^{3}$. Instrumento de planejamento e gestão do município, o Plano Diretor Estratégico, traz consigo inúmeras políticas para melhorar o desenvolvimento municipal. Dentre as diretrizes destacam-se os artigos que abordam aspectos urbanos e ambientais e a

\footnotetext{
${ }^{2}$ Sobre este estudo ver o artigo Perfil Ambiental de uma metrópole brasileira: Curitiba, seus parques e bosques de Márcio de Oliveira.

${ }^{3}$ ARAXÁ. Lei no 5.998, de 20 de junho de 2011. Plano Diretor Estratégico de Araxá.

Revista Cerrados, Montes Claros/MG, v.17, n. 1, p. 240-256, jan./jun.-2019.
} 
LEITE, L. G. F

Áreas verdes de Araxá (MG): questões socioambientais da "Matinha" do bairro Boa Vista

gestão urbana e ambiental. O artigo 55 do PDE (2011) sugere "A implantação de um sistema de áreas verdes qualificando os espaços, com base em projetos de paisagismo, destinados à recreação e à preservação da vegetação existente", a área verde do Bairro Boa Vista é um dos locais apontados pelo artigo, mas os projetos propostos não foram executados.

O Capítulo VII, em seu artigo 58 (2011), faz menção as Áreas de Interesse Ambiental - AIA do município. As áreas são as seguintes: "o Parque do Cristo; toda encosta leste da Avenida Dâmaso Drummond e córrego Terêncio Pereira; a área da Mata do bairro Boa Vista e; Área do IBAMA na região da Avenida Ecológica”. De acordo com o parágrafo primeiro, os locais são destinados à criação e implantação de parques urbanos ou de unidades de conservação de âmbito municipal com o objetivo de proteger as nascentes e a vegetação nativa, porém, não existe qualquer projeto por parte do poder público para execução desta proposta do Plano Diretor.

\section{BAIRRO BOA VISTA: APONTAMENTOS SOBRE O LUGAR}

A cidade apresenta inúmeras áreas verdes, que de acordo com a legislação nacional são classificadas como Áreas de Preservação Permanente, a maior delas localizada na Zona Oeste de Araxá, especificamente no bairro Boa Vista (Mapa 01 e Figura 01). É importante ressaltar que a qualidade de vida urbana está intimamente ligada a áreas verdes segundo Loboda e Angelis (2005) e, portanto, é muito importante refletir o papel destas no cotidiano da sociedade em meio ao urbano.

No entorno da Área Verde da Matinha no bairro Boa Vista, objeto de análise deste trabalho, é possível observar a dinâmica socioambiental em que a população do entorno está inserida, adiante neste artigo, algumas imagens serão apresentadas para melhor elucidação. A área verde (Mapa 02) é classificada pelo Plano Diretor Estratégico de Araxá (2011) como Área de Interesse Ambiental (AIA) em seu artigo 58, portanto, este nome e "Matinha" serão adotados a partir de então para se referir ao espaço. Está delimitada pelas casas e ruas do bairro em um perímetro de dois quilômetros, é impossível não notar, mesmo que de forma indireta, a relação da população local com a área de estudo. 
LEITE, L. G. F

Áreas verdes de Araxá (MG): questões socioambientais da "Matinha" do bairro Boa Vista

Mapa 01. Localização do bairro Boa Vista na malha urbana de Araxá



Fonte: IPDSA, Instituto de Planejamento e Desenvolvimento Sustentável de Araxá. Org.: Elaborado pelo autor, 2014.

Figura 01. Área Verde do bairro Boa Vista.

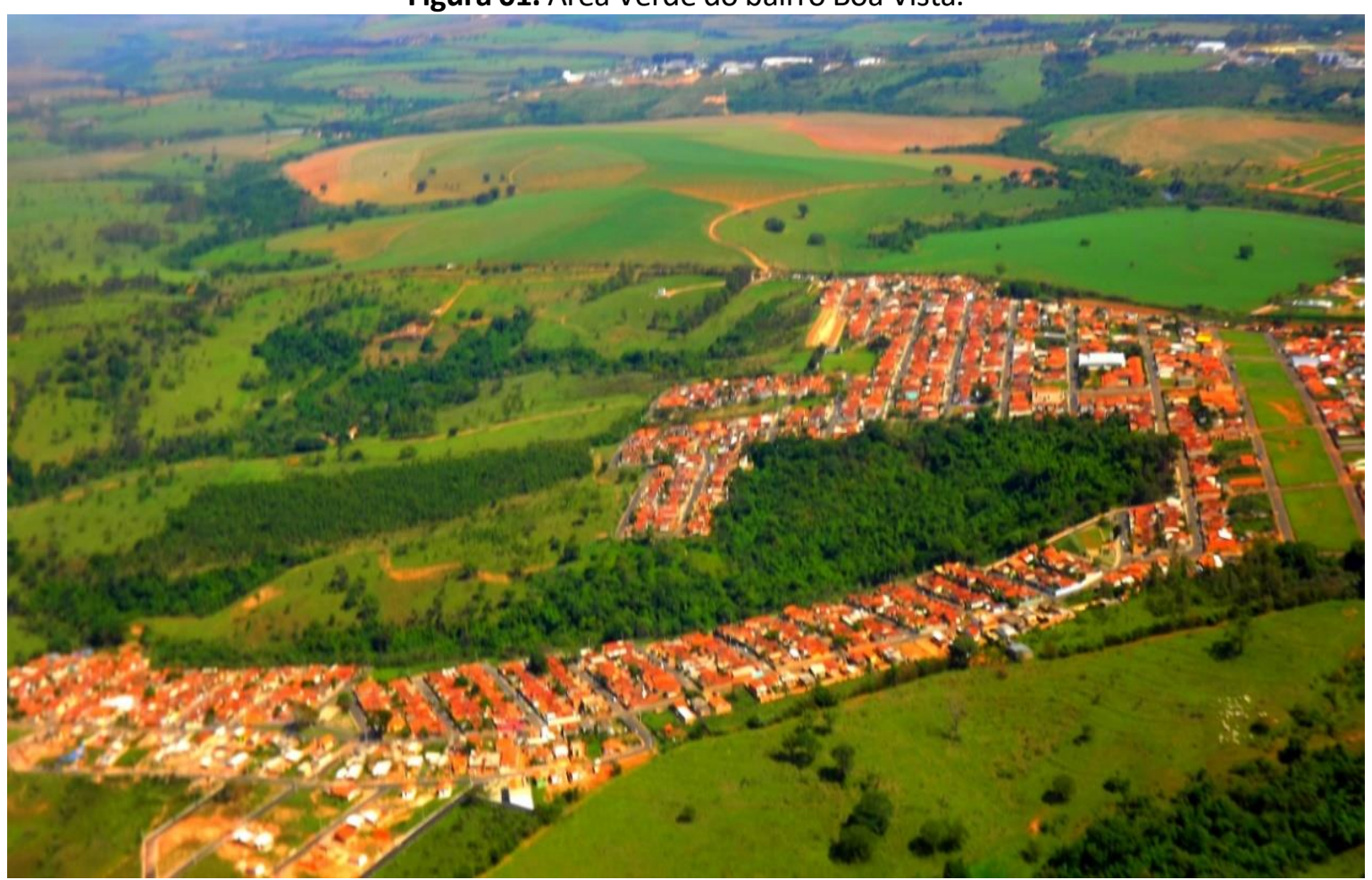

Fonte: Do autor, 2014.

Revista Cerrados, Montes Claros/MG, v.17, n. 1, p. 240-256, jan./jun.-2019. 
LEITE, L. G. F.

Áreas verdes de Araxá (MG): questões socioambientais da "Matinha" do bairro Boa Vista

Mapa 02. Bairro Boa Vista: mapa de uso de solo

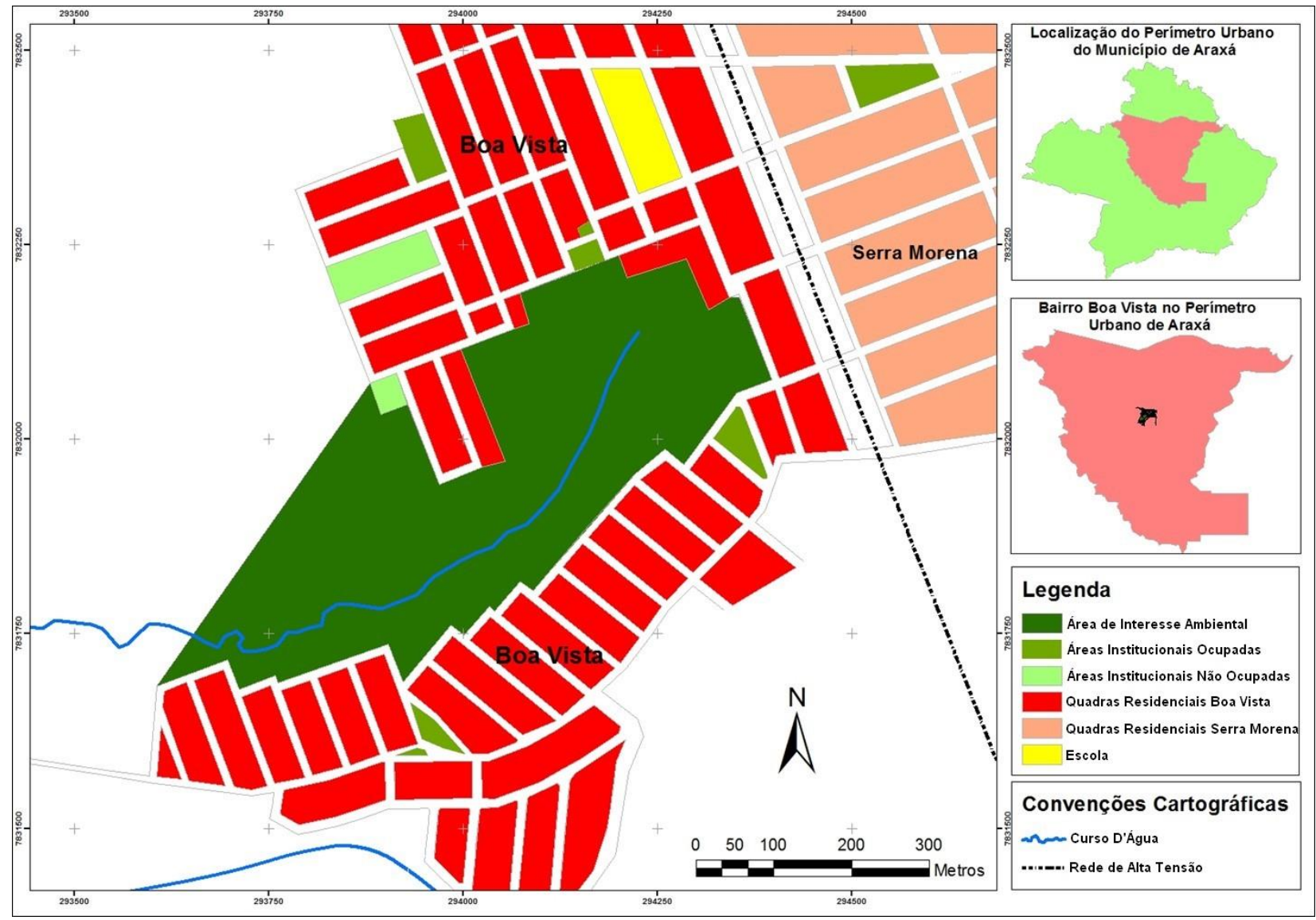

Fonte: IPDSA, Instituto de Planejamento e Desenvolvimento Sustentável de Araxá. Org.: Elaborado pelo autor, 2014.

Os trabalhos de campo no local permitem apontar, atualmente, quatro dinâmicas diferentes em relação ao entorno da Área de Interesse Ambiental do bairro Boa Vista. Dessa forma, o perímetro é classificado do seguinte modo: espaço cercado com tela de proteção (setor leste), bordas que fazem divisa com terrenos residenciais (setor oeste), espaço aberto na parte alta (setor norte) e espaço aberto na parte baixa (setor sul).

No setor sul da área, não existe estrutura física que separa a calçada da área verde. É o local em pior situação, devido ao descarte acentuado de diversos tipos de resíduos, o que evidência a falta de conscientização socioambiental e fiscalização do local por parte do poder público. Em todo o perímetro dessa área, os mais diversos materiais são descartados: entulho de construção civil, lixo orgânico, animais domésticos mortos, lixo doméstico e eletrodomésticos (Figuras 02 e 03). 
LEITE, L. G. F.

Áreas verdes de Araxá (MG): questões socioambientais da "Matinha" do bairro Boa Vista

Figuras 02 e 03. Descarte de eletrodomésticos na "Matinha" do bairro Boa Vista e entulho nas calçadas.

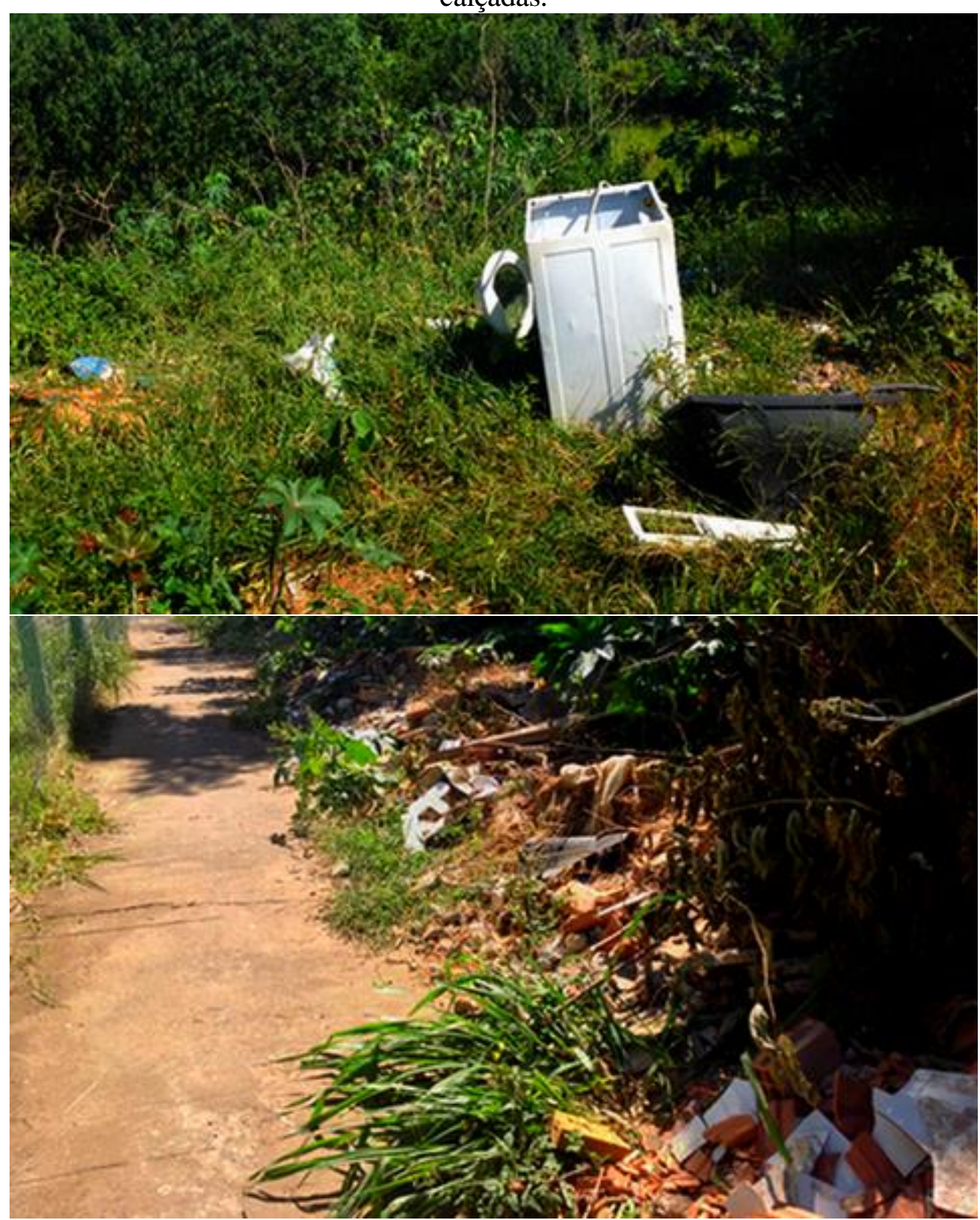

Fonte: Do autor, 2014.

Inúmeros são os problemas causados pelo lixo, agravados pela proximidade com o leito do curso d'água. Materiais líquidos, provenientes da decomposição de animais mortos e do lixo doméstico descartados na área, causam contaminação do solo e do lençol freático que alimentam os cursos hídricos, comprometendo a qualidade da água. A enxurrada da chuva transporta lixo e entulho depositados incorretamente, o que pode causar problemas no leito do córrego. 
LEITE, L. G. F.

Áreas verdes de Araxá (MG): questões socioambientais da "Matinha" do bairro Boa Vista

No setor norte, onde também não existe cerca de proteção, o problema com o lixo é evidente, mas a quantidade descartada é menor que na parte sul da Matinha. Lixo doméstico não foi observado, mas quantidades consideráveis de entulho, eletrodomésticos e móveis sem utilidade são depositadas na extremidade da área.

Nas visitas de campo, é perceptível o descaso com o bairro e com a vegetação remanescente que poderia exercer uma função que não adotasse as características de um "lixão". Em relação ao perímetro circundado pelas residências, o acesso é muito restrito, mas é possível visualizar que as casas que dividem espaço com a vegetação nativa, possuem muros, separando os quintais do espaço natural. Alguns moradores do entorno fizeram uso de um espaço no local onde a vegetação é menos densa para o cultivo (Figura 04), o que interfere na dinâmica natural da mata nativa, corrobora a ausência de projetos de educação ambiental com a comunidade.

Figura 04. Bananeiras plantadas na Área de Preservação Especial

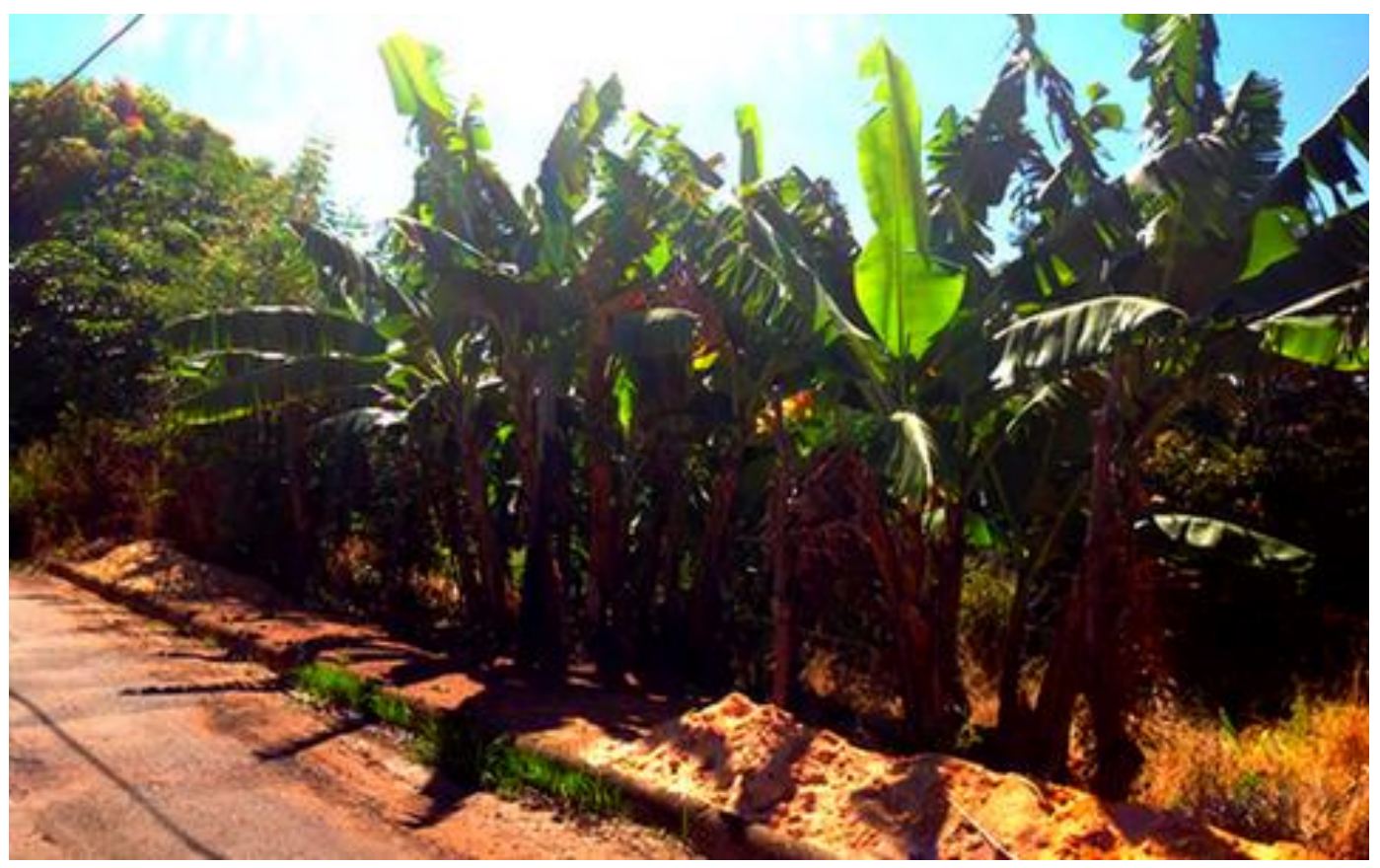

Fonte: Do autor, 2014.

$\mathrm{Na}$ borda leste existe uma tela de proteção, trazendo outro aspecto, o que diferencia o local dos demais perímetros da área. A estrutura com tela coibe o descarte de lixo e protege com maior efetividade as áreas verdes, já que a nascente está próxima desta porção. Visualmente, a tela de proteção traz a sensação de conservação (Figura 05), contudo, o 
LEITE, L. G. F

Áreas verdes de Araxá (MG): questões socioambientais da "Matinha" do bairro Boa Vista

calçamento não recebe a manutenção adequada, é irregular, não proporciona o mínimo de segurança aos pedestres, principalmente àqueles com dificuldade de locomoção. Este é o local com a menor quantidade de materiais inadequados descartados. Diante disso, a qualidade ambiental do bairro seria mais elevada, caso todo o entorno da Área de Interesse Ambiental recebesse o mesmo tratamento e cuidado.

Figura 05. Perímetro leste da "Matinha"

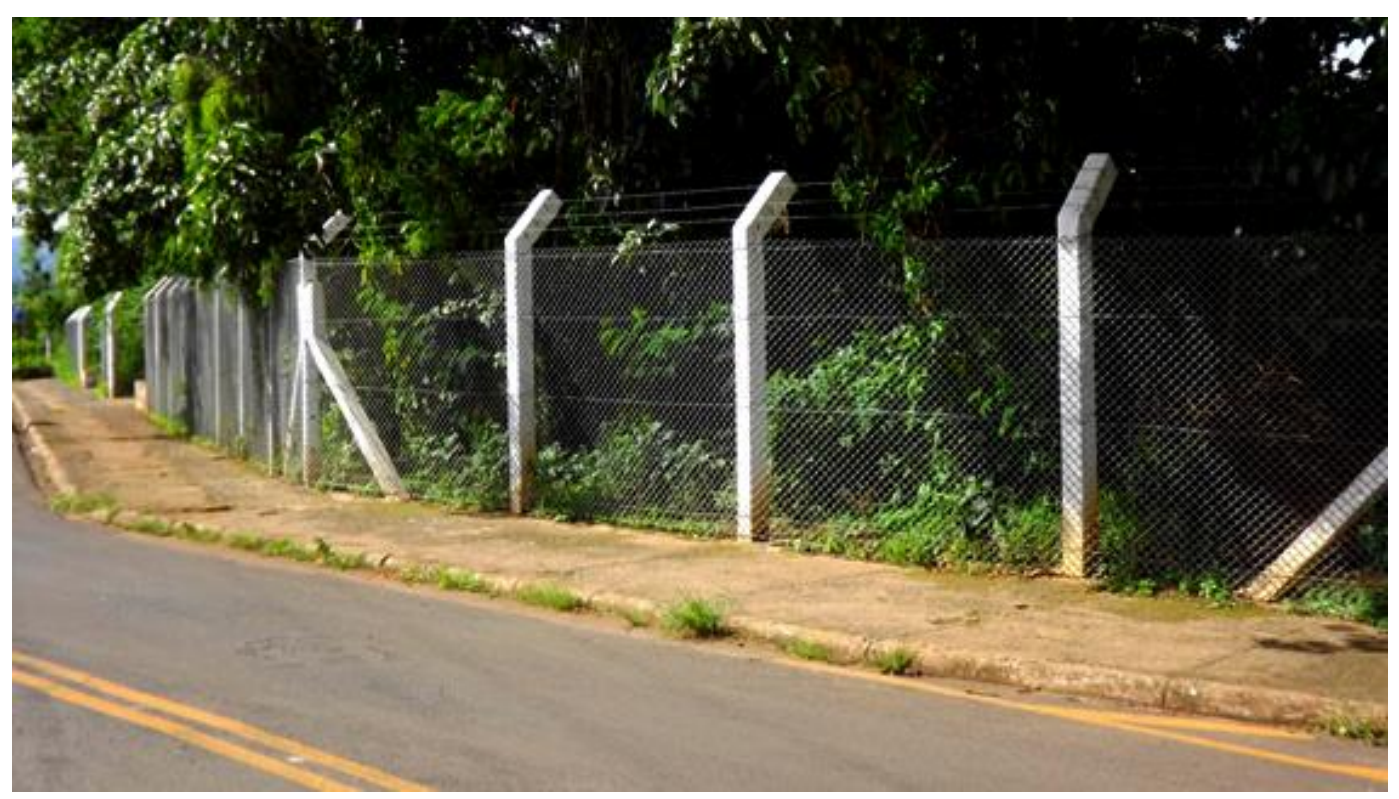

Fonte: Do autor, 2014.

Em duas oportunidades, visitas a área das nascentes foram realizadas com o objetivo de visualizar a conservação do curso d'água e a vegetação da mata ciliar. Cerca de 10 metros após as ruas e casas próximas, observa-se condições de conservação melhores que nas proximidades da margem com pouca presença de lixo e materiais descartados, quase não encontrados nas proximidades do curso d'água. A água (Figura 06) do pequeno córrego é cristalina, a vegetação é bastante densa e protege muito bem a nascente, onde são observados afloramentos de Micaxisto pertencentes ao Grupo Araxá.

A vegetação é muito densa, por conseguinte, a sua conservação é fundamental, uma vez que este espaço ameniza problemas ambientais e contribui significativamente com um microclima mais agradável e ameno. Distante $1 \mathrm{~km}$ do local a temperatura sofre um aumento de cerca de $1,6^{\circ} \mathrm{C}$, contabilizados através de um termômetro. 
LEITE, L. G. F.

Áreas verdes de Araxá (MG): questões socioambientais da "Matinha" do bairro Boa Vista

Figura 06. Região próxima a nascente

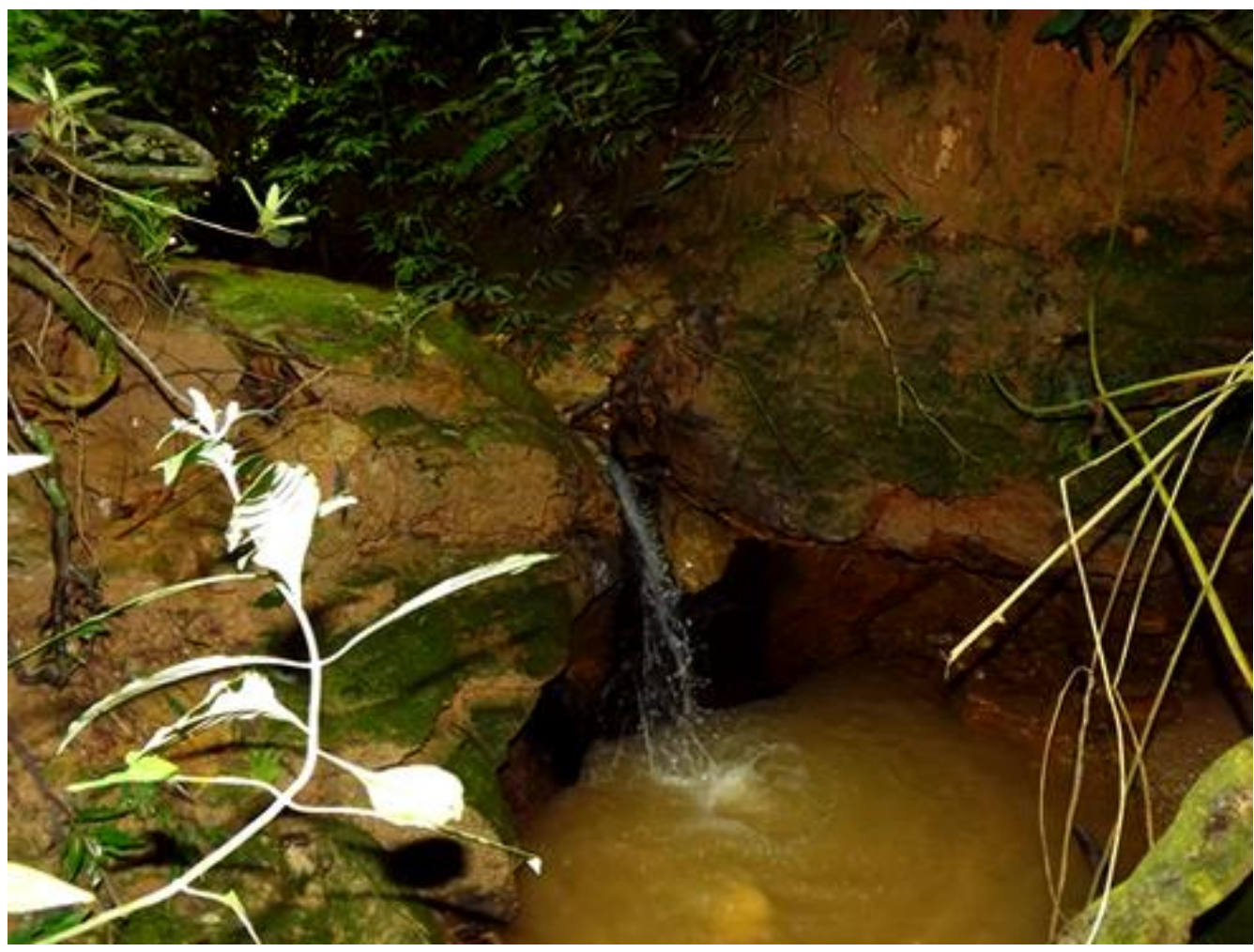

Fonte: Do autor, 2014.

O mapa 03 apresenta as condições visualizadas dentro da mata quanto a sua degradação, definidas em alta, média e baixa degradação. Os critérios adotados para essa definição foram elencados por meio de observação direta na área e são baseados em quantidade, tipo de lixo e grau de conservação da área nativa. Nas regiões de alta degradação, por exemplo, a grande quantidade e variedade de resíduos depositados são fundamentais para a definição desse parâmetro. As áreas de média e baixa degradação apresentam condições consideradas muito boas quando comparadas as áreas mais prejudicadas com o lixo (alta degradação) presente em uma quantidade bem acentuada prejudicando toda a dinâmica ambiental. Nota-se que as áreas que fazem divisa com residências estão bem conservadas, o que é bastante positivo. A ausência de um manejo adequado da "Matinha" é preocupante, pois este poderia proporcionar importante equilíbrio entre meio ambiente e sociedade, Lapoix (1977) aborda com grande propriedade essa necessidade. 
LEITE, L. G. F.

Áreas verdes de Araxá (MG): questões socioambientais da "Matinha" do bairro Boa Vista

Mapa 03. Estado de conservação da "Matinha" do bairro Boa Vista.

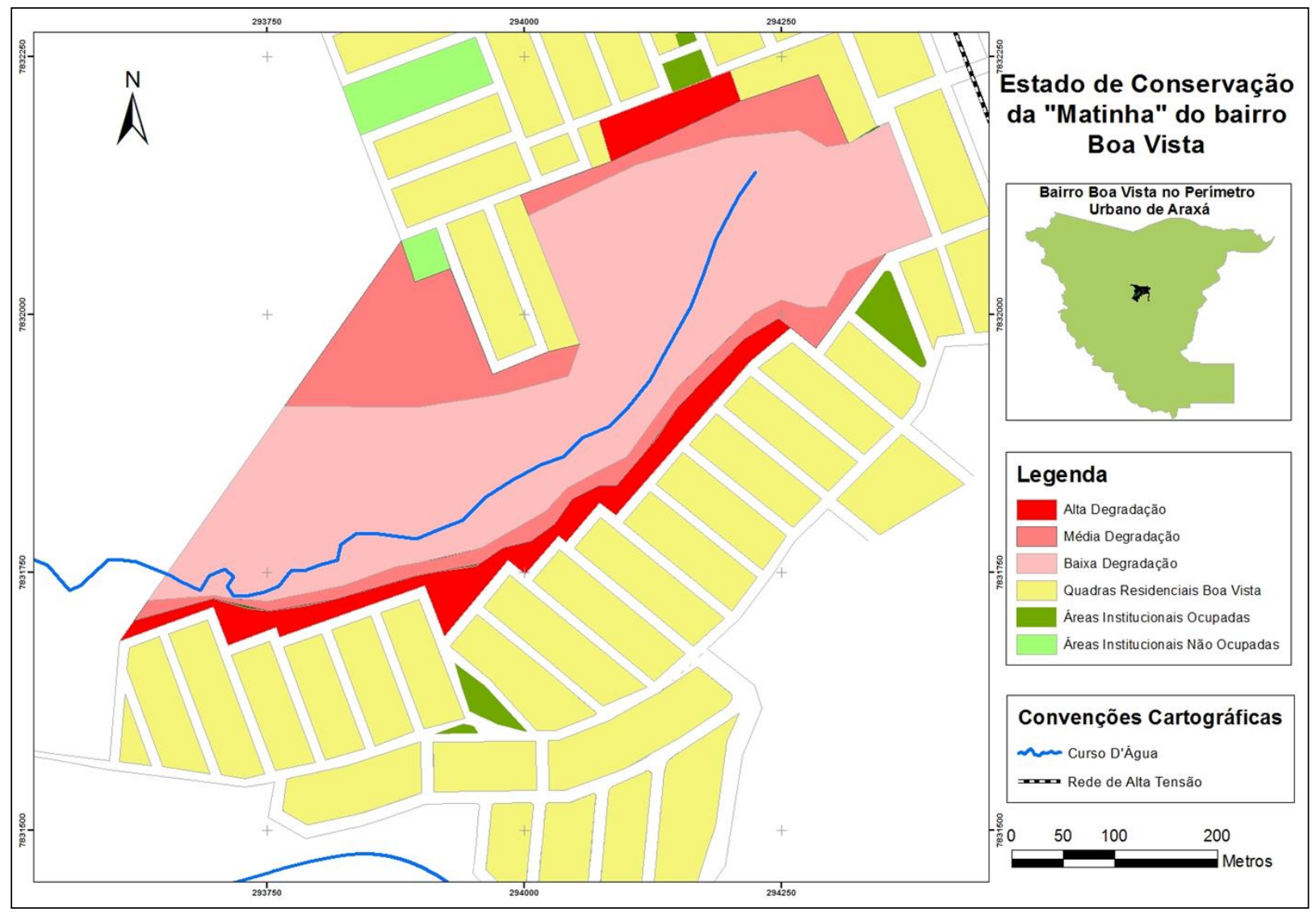

Fonte: IPDSA, Instituto de Planejamento e Desenvolvimento Sustentável de Araxá. Org.: Elaborado pelo autor, 2014.

Durante os trabalhos de campo pelo bairro, é possível notar raros espaços para lazer. São encontrados na área norte, um campo de futebol e uma pequena praça nas proximidades do centro de convivência comunitário; a região sul possui duas praças. Todos os equipamentos de lazer se encontram em péssimo estado para uso e depredados (Figura 07). No entanto, esses espaços ainda funcionam como ambientes para recreação apesar de todas as limitações, já que o bairro carece de áreas de lazer. Consequentemente, o trabalhador encontra dificuldades para uso das estruturas em seus momentos de descanso na vizinhança. 
LEITE, L. G. F.

Áreas verdes de Araxá (MG): questões socioambientais da "Matinha" do bairro Boa Vista

Figura 07. Praça do Cruzeiro na região sul do bairro Boa Vista.

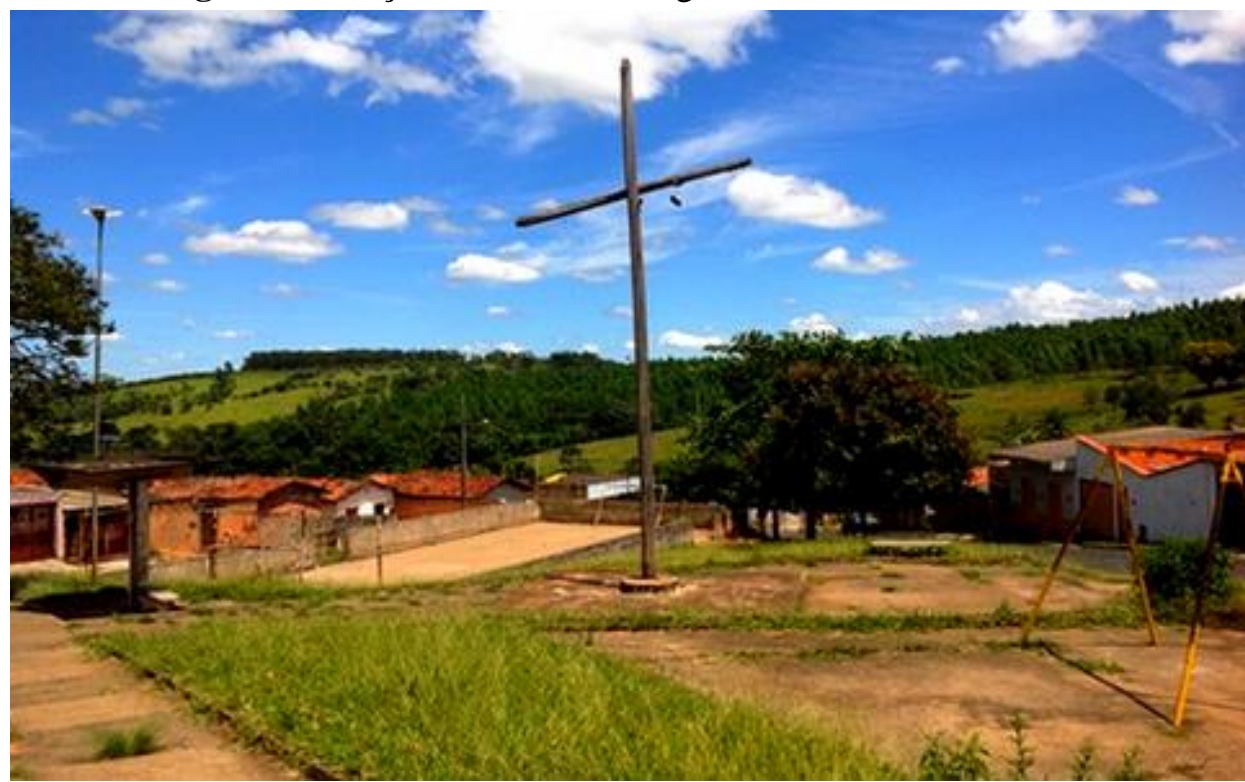

Fonte: Do autor, 2014.

\section{SOCIEDADE E VISÃO AMBIENTAL: ALGUMAS REFLEXÕES}

Com o objetivo de compreender a visão dos moradores do bairro Boa Vista sobre a Área de Interesse Ambiental, realizou-se pesquisa empírica abordando a relação atual e os anseios da população sobre o futuro da área. Foram aplicados 43 questionários, o que corresponde a cerca de 1\% dos moradores. Diante de informações fornecidas pela Prefeitura de Araxá (2014), a população estimada do bairro é de quatro mil habitantes. Os habitantes abordados estão distribuídos aleatoriamente pelas quadras do bairro, alguns mais próximos, outros mais distantes da AIA. É perceptível como a sensibilidade e o entendimento sobre a área escolhida para este trabalho mudam de acordo com a proximidade da moradia do entrevistado com o objeto de estudo. Do universo de 43 entrevistados, 18 eram homens (42\%) e 25 eram mulheres (58\%). O gráfico 01 apresenta a faixa etária dos entrevistados:

Como se pode observar 58\% dos entrevistados apresenta idade entre 40 e 60 anos, isso mostra uma população local composta em sua maioria, por pessoas em idade economicamente ativa. Sobre a importância ambiental do bairro e a relação dos moradores com a Matinha, a primeira abordagem é a respeito da nascente e seu curso hídrico presente no local. Os entrevistados foram questionados se sabiam da existência do curso d'água e todos os moradores responderam que sim. As respostas positivas dessa primeira questão permitiram 
LEITE, L. G. F.

Áreas verdes de Araxá (MG): questões socioambientais da "Matinha" do bairro Boa Vista

conduzir as perguntas ao tema ligado ao meio ambiente, uma vez que os moradores têm conhecimento do recurso essencial da área, a água.

Gráfico 01. Faixa etária dos moradores do bairro Boa Vista entrevistados.

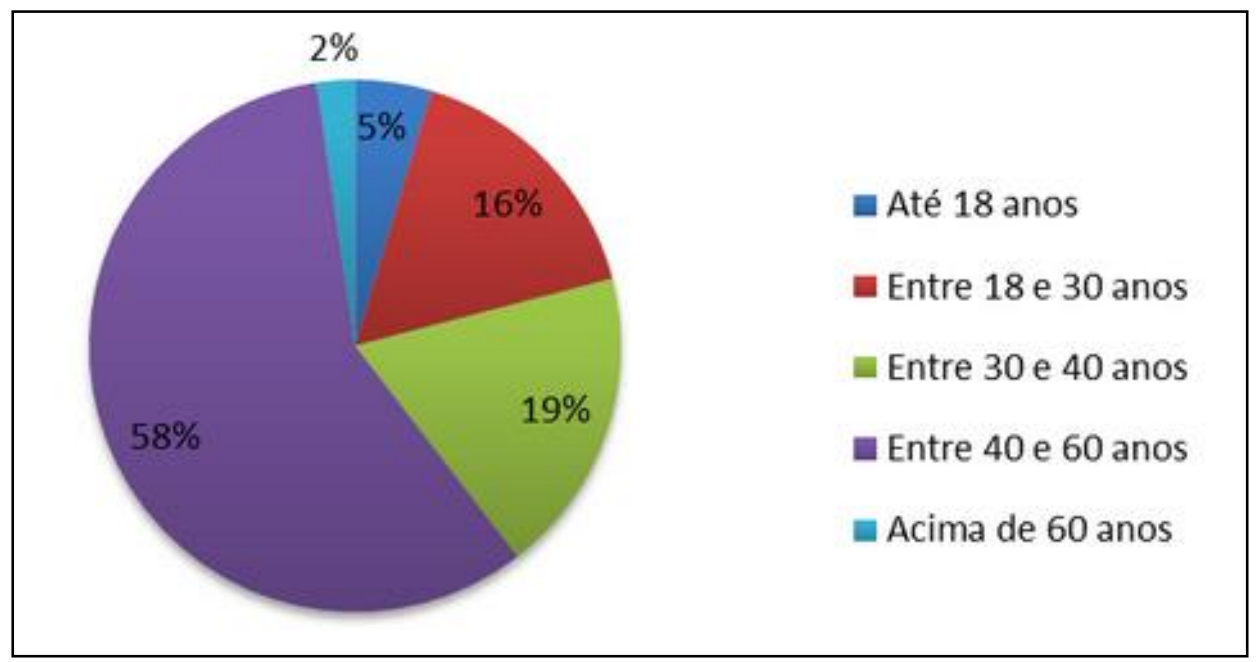

Fonte: Pesquisa de Campo, 2014. Org.: Elaborado pelo autor, 2014.

Embora a "Matinha" do bairro Boa Vista tenha como principal função, proteger sua nascente e o seu pequeno córrego, um dos seus problemas é a degradação e a deposição de lixo que acompanha o entorno, conforme relatado nos trabalhos de campo. A segunda questão sobre a percepção ambiental trouxe a seguinte pergunta: Quais problemas ambientais você identifica na região da "Matinha"? O entrevistado pode responder espontaneamente a pergunta. A tabela 01 apresenta as respostas dadas pelos moradores.

Tabela 01. Problemas Ambientais da "Matinha" citados pelos moradores

\begin{tabular}{cc}
\hline Problema Ambiental & Percentual \\
\hline Acúmulo de Lixo & $33 \%$ \\
Falta de Proteção da Área & $30 \%$ \\
Queimadas & $15 \%$ \\
Poluição das Águas & $10 \%$ \\
Poluição do Ar & $5 \%$ \\
Desmatamento & $4 \%$ \\
Outros & $4 \%$ \\
\hline
\end{tabular}

Fonte: Pesquisa de Campo, 2014. Org.: Elaborado pelo autor, 2014.

Revista Cerrados, Montes Claros/MG, v.17, n. 1, p. 240-256, jan./jun.-2019. 
LEITE, L. G. F.

Áreas verdes de Araxá (MG): questões socioambientais da "Matinha" do bairro Boa Vista

Os maiores problemas relatados pelos habitantes do bairro são referentes ao acúmulo de lixo (33\%) e a falta de proteção da área (30\%). A quantidade depositada de lixo na borda da área é enorme. Alguns moradores relataram que esse tipo de problema pode ser resolvido com conscientização ambiental e campanhas educativas. A coleta de lixo orgânico no bairro é realizada três vezes por semana - às segundas-feiras, às quartas-feiras e às sextasfeiras, e também conta com coleta de lixo seletivo, às terças-feiras e às quintas-feiras. A falta de proteção física do espaço contribui significativamente para a degradação provocada pela deposição de lixo, visto que na pequena área cercada com tela o volume de resíduos é muito inferior.

A respeito dos problemas ambientais, os entrevistados puderam destacar até três respostas. O problema com queimadas foi citado, mas de maneira inferior, já que esse tipo de situação acontece esporadicamente. A poluição das águas foi mencionada, alguns moradores relacionam a deposição de lixo como causador desse tipo de problema. O item "outros", apontado pelos moradores, não se pauta diretamente em problemas ambientais, todos os entrevistados apontam problemas de segurança pública.

Em relação à atribuição dos problemas ambientais do bairro, os moradores classificam o poder público como principal culpado pelas situações observadas. $\mathrm{O}$ gráfico 02 apresenta um comparativo na opinião dos moradores.

Gráfico 02. Responsáveis pelos problemas ambientais.

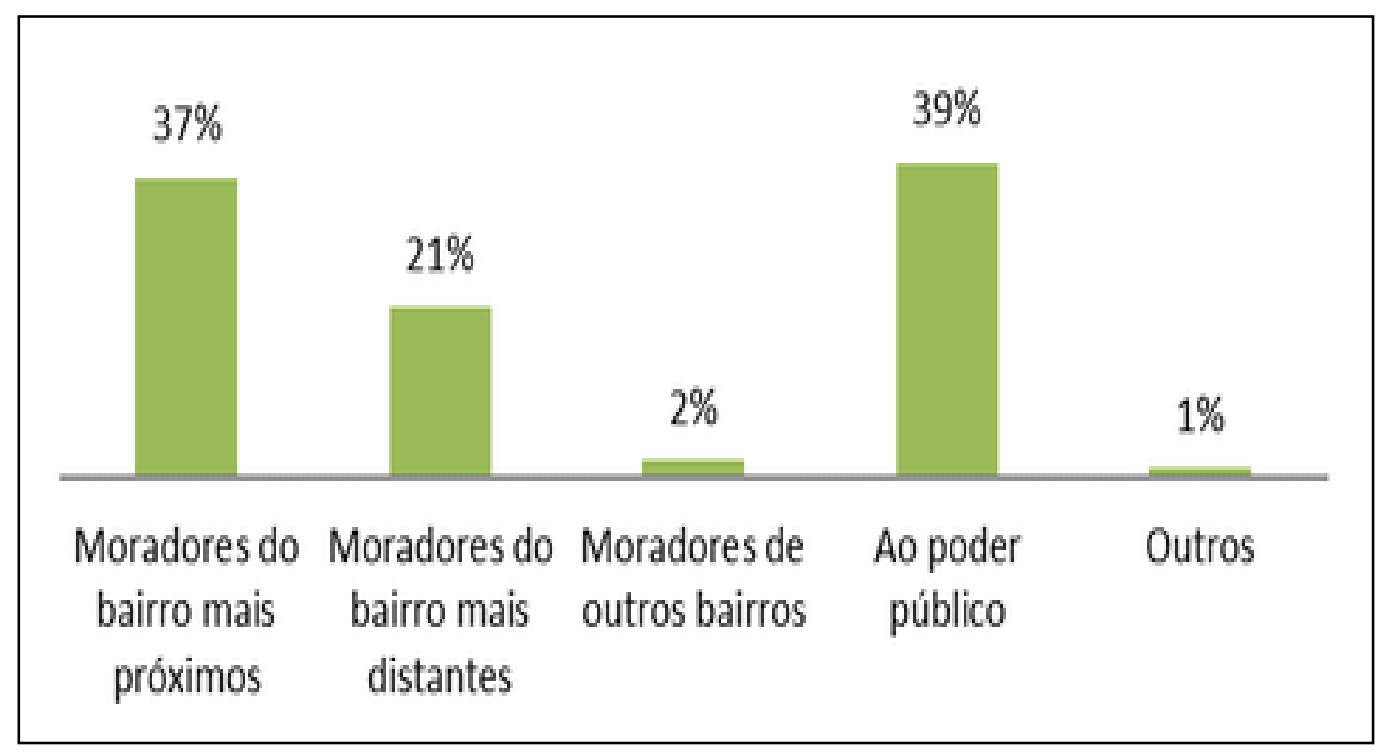

Fonte: Pesquisa de Campo, 2014. Org.: Elaborado pelo autor, 2014.

Revista Cerrados, Montes Claros/MG, v.17, n. 1, p. 240-256, jan./jun.-2019. 
LEITE, L. G. F.

Áreas verdes de Araxá (MG): questões socioambientais da "Matinha" do bairro Boa Vista

Observam-se paralelos quanto à atribuição da responsabilidade. Segundo os entrevistados, que residem áreas mais distantes do local, os habitantes mais próximos seriam causadores secundários do problema. A mesma tendência não foi constatada entre os entrevistados que residem próximo das bordas. Estes apontam a si mesmos e moradores mais distantes como responsáveis ao excesso de lixo encontrado no local. Nesse momento é perceptível um impasse fundamental no entendimento dos processos de degradação, os próprios moradores que poderiam contribuir para o cenário positivo, ajudam a degradar e esperam do poder público a solução do problema.

Diante da situação atual do lugar, em que há ausência do governo municipal associada à falta de compromisso da comunidade, impedindo que o local seja frequentado pelos moradores como opção de lazer. O contato da maioria dos habitantes é de passagem por questões de deslocamento, já que as vias que circundam a "Matinha" são coletoras de parte do tráfego de carros e são vias de pedestres do bairro. Questionados sobre a frequência semanal com que saem de casa para apenas visitar o espaço os moradores responderam o seguinte (Tabela 02):

Tabela 02. Frequência semanal de visita atual dos moradores:

\begin{tabular}{ccc}
\hline Frequência Semanal & Número de Moradores & Percentual \\
\hline Nenhuma vez & 36 & $84 \%$ \\
Uma vez & 2 & $5 \%$ \\
Duas a três vezes & 2 & $5 \%$ \\
Três a cinco vezes & 1 & $1 \%$ \\
Mais de cinco vezes & 2 & $5 \%$ \\
\hline Fonte: Pesquisa de Campo, 2014. Org.: Elaborado pelo autor, 2014.
\end{tabular}

O resultado evidencia a falta de atratividade do local. Alguns dos entrevistados relataram que só o visitam por questão de tempo ocioso, ou mesmo para passeio com animais de estimação. Interrogados sobre prioridade em estruturas a serem construídas e ações para o entorno da AIA e em benefício do bairro, observa-se os seguintes apontamentos (Tabela 03): 
LEITE, L. G. F.

Áreas verdes de Araxá (MG): questões socioambientais da "Matinha" do bairro Boa Vista

Tabela 03. Estruturas e Ações necessárias na Área Verde na opinião dos moradores:

\begin{tabular}{cc}
\hline Estruturas & Percentual \\
\hline Calçadas & $21 \%$ \\
Cercas de Proteção & $19 \%$ \\
Fiscalização & $18 \%$ \\
Equipamentos para Atividades Físicas & $13 \%$ \\
Segurança & $12 \%$ \\
Praças & $8 \%$ \\
Quadras Poliesportivas & $8 \%$ \\
Outros & $1 \%$ \\
\hline
\end{tabular}

Fonte: Pesquisa de Campo, 2014. Org.: Elaborado pelo autor, 2014.

A ausência de calçadas é a principal reivindicação dos moradores, já que esse tipo de estrutura facilita caminhadas no entorno e incentiva a população a contemplar a paisagem natural. Cercas de proteção foram bastante lembradas pelos cidadãos do bairro, pois protegem a área contra o descarte de lixo e auxiliam na conservação da natureza, porém para que funcionem é necessária massiva fiscalização e conscientização da população local.

Equipamentos para atividades físicas, outro elemento mencionado de forma significativa pelos moradores, podem transformar a área em espaço de lazer, sem a necessidade de grandes deslocamentos para essas atividades. Cabe ressaltar que o inciso primeiro do artigo 58 do Plano Diretor de Araxá menciona que as Áreas de Interesse Ambiental serão destinadas à implantação de Parques Urbanos ou Unidades de Conservação, caso do bairro Boa Vista.

Outra questão abordada pelos habitantes locais refere-se ao destino adequado para área em análise. Observadas as respostas da questão anterior (sobre ações necessárias à ocupação da área), elas se relacionam bem e existe coerência com os anseios da população na perspectiva sobre o futuro da Matinha. De acordo com os dados obtidos, há anseios pela completa conservação ambiental do local. Os moradores puderam assinalar até três opções. $\mathrm{O}$ gráfico 03 apresenta os resultados. 
Áreas verdes de Araxá (MG): questões socioambientais da "Matinha" do bairro Boa Vista

Gráfico 03. Destino Adequado para "Matinha" do Boa Vista.

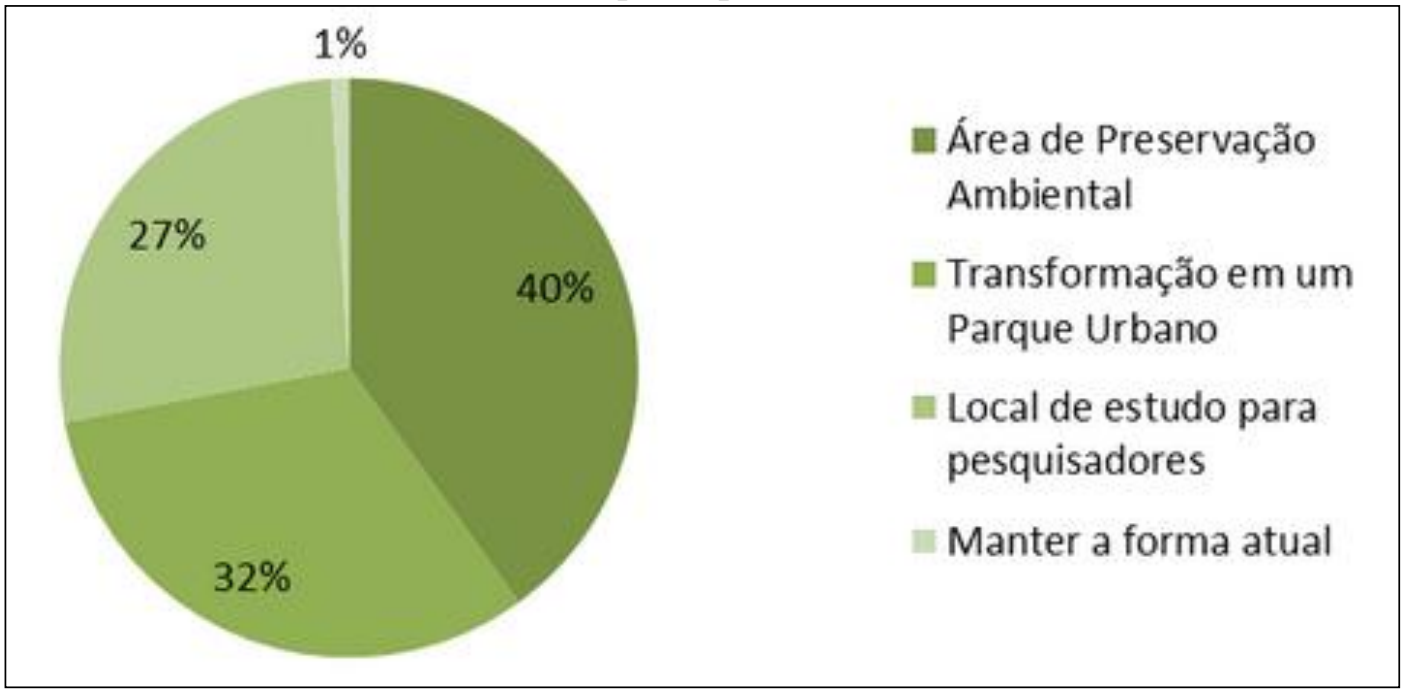

Fonte: Pesquisa de Campo, 2014. Elaborado pelo autor, 2014.

Diante de tudo que já foi exposto, cabe salientar a necessidade de conservação do local. Ressaltada a vasta quantidade de espécies de fauna e flora encontradas e a importância da nascente para o ciclo hidrográfico da bacia que compõe. Por sua vez, a adoção de políticas conservacionistas aliadas à transformação do espaço em Parque Urbano, poderá oferecer qualidade de vida aos habitantes locais, conforme o caso de Curitiba evidenciado por Oliveira (1996), e contribuir significativamente na conscientização dos moradores quanto à importância da conservação do local.

Outro ponto que chama a atenção é a sensibilidade das pessoas em relação ao local e sua riqueza natural. Muitos moradores apoiam a ideia de que o local se torne espaço de pesquisas científicas, importantes não só para o bairro, mais para a cidade de Araxá, embora os moradores sejam em parte responsáveis pela degradação.

Caso ocorram mudanças como as sugeridas pelos moradores, a frequência (Tabela 04) com que a população irá visitar a "Matinha" se inverte quando comparada ao cenário atual. Agregar-se-á valor ao local que deixará o estereótipo de problema e se transformará em uma ferramenta social que possibilita contemplação e lazer. Tal mudança favorecerá ao bairro, que é uma área residencial de classe média baixa, incidindo considerável valorização. Agregará valor para a cidade em geral, pois terá mais uma opção pública de lazer em Araxá. 
LEITE, L. G. F.

Áreas verdes de Araxá (MG): questões socioambientais da "Matinha" do bairro Boa Vista

Tabela 04. Frequência de visita semanal dos moradores após as mudanças sugeridas.

\begin{tabular}{ccc}
\hline Frequência Semanal & Número de Moradores & Percentual \\
\hline Nenhuma vez & 1 & $1 \%$ \\
Uma vez & 4 & $9 \%$ \\
Duas a três vezes & 22 & $51 \%$ \\
Três a cinco vezes & 10 & $23 \%$ \\
Mais de cinco vezes & 6 & $16 \%$ \\
\hline
\end{tabular}

Fonte: Pesquisa de Campo, 2014. Elaborado pelo autor, 2014.

Os resultados desse questionário são dados importantes para se pensar em políticas de planejamento ambiental para o bairro. Dentre os entrevistados $63 \%$ reside no bairro Boa Vista há mais de 15 anos e pode contribuir com grande propriedade no debate sobre os problemas ambientais da área. Se por um lado os moradores se enquadram como principais responsáveis por alguns problemas de degradação como o descarte de lixo, os mesmos são os principais atores na busca pela mudança positiva.

\section{CONSIDERAÇÕES FINAIS}

Ao longo deste trabalho procurou-se debater de forma multidisciplinar a necessidade de efetivação do planejamento para as cidades na conservação e adequação das áreas verdes existentes, através de políticas apropriadas. Os núcleos urbanos, hoje, crescem desordenadamente, interferindo de forma negativa nos espaços naturais que têm desaparecido com grande constância nos últimos anos.

O exemplo retratado, que aborda a maior área verde com uma nascente de Araxá, conhecida como "Matinha" do bairro Boa Vista, chama a atenção pela necessidade de implementação de ações que beneficiem o local. É preciso conservar a área que abriga inúmeras espécies de fauna e flora, importantes para o equilíbrio ecológico da cidade e, ao mesmo tempo, pensar o espaço como possibilidade de se tornar um instrumento de lazer e contemplação ambiental para os moradores da região.

Partindo da análise dos instrumentos utilizados para esta pesquisa, percebe-se a necessidade da quebra dos modelos criados pela população local em relação à área verde como espaço problema. Em um primeiro momento, antes de qualquer ação física caberá a 
LEITE, L. G. F.

Áreas verdes de Araxá (MG): questões socioambientais da "Matinha" do bairro Boa Vista

proposição de um amplo e rico trabalho de educação ambiental que mostre com minúcia de detalhes qual o real benefício que esta área poderá trazer se bem conservada ao espaço urbano do bairro. $\mathrm{O}$ trabalho de educação ambiental deve ser executado em parceria com moradores, o conselho comunitário do bairro, os alunos da escola e creche- responsáveis pela educação da maior parte das crianças e adolescentes - do bairro Boa Vista e, ainda, com órgãos ligados ao meio ambiente do governo municipal.

Existe um grande conflito entre a comunidade do bairro, porque são os próprios moradores os responsáveis pela falta de qualidade ambiental da Área de Interesse Ambiental, em virtude de ações inadequadas como o descarte de lixo na margem da Matinha. O paradigma a ser quebrado é fazer com que a população compreenda e assimile a importância real de se conservar o espaço. Estes podem e devem ser os principais agentes e fiscais na manutenção da qualidade ambiental da Matinha. Tal interação reduz a possibilidade de conflitos entre sociedade e natureza.

Após esse primeiro passo, o bairro Boa Vista necessita de investimentos públicos que atendam as inúmeras demandas da região, inclusive no que tange a Áreas de Interesse Ambiental, localizada no bairro. Instrumentos que contemplem a preservação e a conservação da área verde, a manutenção das calçadas e ruas e o cuidado adequado com os espaços de lazer. $\mathrm{O}$ acréscimo de mais áreas de lazer somadas às poucas existentes é uma medida urgente para a qualidade de vida local.

A ausência das autoridades competentes permite a falta de conscientização dos moradores, agentes fundamentais no aumento dos problemas evidenciados. Somente atitudes sérias em benefício da natureza e da valorização da população local, como a implantação de programas de educação ambiental e a ampliação dos equipamentos de lazer favorecerão mudanças positivas da comunidade. É importante que os moradores sejam inseridos em todas as etapas de um processo que vise à construção de um conceito de qualidade ambiental e de vida. $\mathrm{O}$ estudo deste trabalho mostra em alguns pontos o não sentimento de pertencimento a realidade do lugar por parte da população, o que amplia os conflitos socioambientais.

Como sugestão final deste artigo, propõe-se a elaboração de um completo Plano de Manejo com o objetivo de se criar um Parque dentro de um sistema de Unidades de Conservação Municipal. A criação da Unidade de Conservação da "Matinha" do bairro Boa Vista poderá possibilitar a conscientização ambiental e auxiliar na resolução de numerosos problemas encontrados no entorno da área verde. Os referidos problemas prejudicam a Revista Cerrados, Montes Claros/MG, v.17, n. 1, p. 240-256, jan./jun.-2019. 
LEITE, L. G. F.

Áreas verdes de Araxá (MG): questões socioambientais da "Matinha" do bairro Boa Vista

população local, a dinâmica ambiental e os seus recursos naturais - como a própria nascente da área.

Ambientes com as características da Área de Interesse Ambiental do bairro Boa Vista atenuam o clima urbano, valorizam a paisagem natural do bioma em que está inserido, caso do Cerrado em Araxá. Além disso, tornam-se espaços de contemplação e elevam de forma acentuada a qualidade ambiental das áreas próximas. Se pensadas dessa forma, as áreas verdes das cidades passarão a cumprir o seu verdadeiro papel, qual seja proporcionar uma realidade distante do espaço urbano contemporâneo que é edificado apenas com concreto, aproximando os cidadãos da natureza.

\section{REFERÊNCIAS}

AB’SÁBER, A. N. Os Domínios de Natureza no Brasil: Potencialidades Paisagísticas. 7. ed. São Paulo: Atêlie Editorial, 2012.

ALENTEJANO, P. R. R.; ROCHA-LEÃO, O. M. Trabalho de campo: uma ferramenta essencial para os Geógrafos ou um instrumento banalizado? Boletim Paulista de Geografia, São Paulo, n. 84, 2006.

ARAXÁ. Plano Diretor Estratégico de Araxá - Lei n. 5.998. Araxá: Câmara Municipal, 2011.

BRASIL. Decreto-lei 12.651 de 25 de maio de 2012. Dispõe sobre a proteção da vegetação nativa; altera as Leis nos 6.938, de 31 de agosto de 1981, 9.393, de 19 de dezembro de 1996, e 11.428, de 22 de dezembro de 2006; revoga as Leis nos 4.771, de 15 de setembro de 1965, e 7.754, de 14 de abril de 1989, e a Medida Provisória no 2.166-67, de 24 de agosto de 2001; e dá outras providências. In: Diário Oficial da União, Brasília, v. 149, n. 102, p. 1, 28 mai. 2012. Seção 1.

CAVALHEIRO, F., DEL PICCHIA, P. C. D. Áreas Verdes: Conceitos, Objetivos e Diretrizes Para o Planejamento. In: Congresso Brasileiro Sobre Arborização Urbana, 1, 1992, Vitória. Anais. Vitória: 1992, 29-38.

CAVALHEIRO, F.; NUCCI, J.C; GUZZO, P.; ROCHA, Y.T. Proposição de terminologia para o verde urbano. Boletim Informativo da SBAU (Sociedade Brasileira de Arborização Urbana), ano VII, n. 3 - Jul/ago/set de 1999, Rio de Janeiro, p. 7.

IBGE, Instituto Brasileiro de Geografia Estatística. Estimativas de População 2018. Disponível em: < https://www.ibge.gov.br/estatisticas/sociais/populacao/9103-estimativas-depopulacao.html?=\&t=o-que-e $>$ Acesso em: 30/08/2018.

KLIASS, R. G. Parques Urbanos de São Paulo. São Paulo: Pini, 1993.

LAPOIX, F. Cidades verdes e abertas. In: FERRY, M.G. (Coord.) Enciclopédia de Ecologia. São Paulo: EDUSP, 1979, p.324-36. 
LEITE, L. G. F.

Áreas verdes de Araxá (MG): questões socioambientais da "Matinha" do bairro Boa Vista

LIMA, J. E. F. W.; SILVA, E. M. Análise da Situação dos Recursos Hídricos do Cerrado Com Base na Importância Econômica e Socioambiental de Suas Águas. In: IX Simpósio Nacional Cerrado, 2008, Brasília. Anais. Disponível em:

<http://www.cpac.embrapa.br/publicacoes/search_pbl/1?q=An\%C3\%A1lise+econ\%C3\%B4mica $>$ Acesso em: 27/01/2014.

LOBODA, C. R., ANGELIS, B. L. B. Áreas Verdes Públicas Urbanas: Conceitos, Usos e Funções. Ambiência - Revista do Centro de Ciências Agrárias e Ambientais, Guarapuava, v. 1, n. 1, jan-jun. 2005.

MELAZZO, G. C. A cidade, o meio ambiente e os parques urbanos: Um Estudo da Percepção Ambiental no Parque Municipal Vitório Siquierolli. Uberlândia: UFU, 2003. Monografia, Instituto de Geografia, Universidade Federal de Uberlândia, 2003.

MMA, Ministério do Meio Ambiente. Áreas de Preservação Permanente Urbanas. Disponível em: <http://www.mma.gov.br/cidades-sustentaveis/areas-verdes-urbanas/\%C3\%A1reas-deprote\%C3\%A7\%C3\%A3o-permanente> Acesso em: 30/09/2013.

$30 / 01 / 2014$

. Bioma Cerrado. Disponível em: <http://www.mma.gov.br/biomas/cerrado> Acesso em:

. Parques e Áreas Verdes. Disponível em: <http://www.mma.gov.br/cidades-

sustentaveis/areas-verdes-urbanas/parques-e-\%C3\%A1reas-verdes> Acesso em: 30/09/2012.

MOURA, A. R., NUCCI, J. C. Cobertura Vegetal Em Áreas Urbanas - O Caso do Bairro de Santa Felicidade - Curitiba - PR. Geografia: Ensino \& Pesquisa, Santa Maria, v. 12, p. 16821698, 2008.

NUCCI, J. C. Qualidade ambiental e adensamento urbano: um estudo de ecologia e planejamento da paisagem aplicado ao distrito de Santa Cecília (MSP). $2^{\mathrm{a}}$ ed. - Curitiba: O Autor, 2008.

OLIVEIRA, M. Perfil Ambiental de uma metrópole brasileira: Curitiba, seus parques e bosques. Revista Paranaense de Desenvolvimento, Curitiba, n. 88, p.37-54, 1996.

SANTOS, M. A Natureza do Espaço: Técnica e Tempo, Razão e Emoção. 4. ed. São Paulo: EDUSP, 2006.

WWF - Brasil. Berço das Águas. Disponível em:

$<\mathrm{http} / / /$ www.wwf.org.br/natureza_brasileira/areas_prioritarias/cerrado/bercodasaguas/> Acesso em: 30/12/1016. 
Luis Guilherme Ferreira Leite - Possui Graduação em Geografia pela Universidade Federal de Uberlândia (UFU). Atualmente é Mestrando do Programa de Pós-Graduação em Geografia da Universidade Federal de Uberlândia (UFU).

Artigo recebido em: 19 de dezembro de 2018.

Artigo aceito em: 26 de junho de 2019.

Artigo publicado em: 28 de junho de 2019. 